\title{
Risk factors for mortality in hospitalized patients with COVID-
}

\section{9 from three hospitals in Peru: a retrospective cohort study}

\section{[version 1; peer review: 2 approved]}

\author{
Cristian Díaz-Vélez (iD)1,2, Diego Urrunaga-Pastor (iD)3, Anthony Romero-Cerdán4, \\ Eric Ricardo Peña-Sánchez ${ }^{5}$, Jorge Luis Fernández Mogollon (iD2, \\ Julio Darwin Cossio Chafloque2, Gaston Cristobal Marreros Ascoy6, \\ Vicente A. Benites-Zapata (1D) \\ ${ }^{1}$ Universidad Señor de Sipán, Escuela de Medicina, Chiclayo, Peru \\ ${ }^{2}$ Hospital Nacional Almanzor Aguinaga Asenjo, EsSalud, Chiclayo, Peru \\ 3 Universidad Científica del Sur, Lima, Peru \\ ${ }^{4}$ ADIECS Asociación para el Desarrollo de la Investigación Estudiantil en Ciencias de la Salud, Universidad Nacional Mayor de San \\ Marcos, Lima, Peru \\ ${ }^{5}$ Dirección Ejecutiva de Enfermedades No Transmisibles, Ministerio de Salud, Peru \\ ${ }^{6}$ Hospital Luis Heysen Incháustegui, Chiclayo, Peru \\ 7Universidad San Ignacio de Loyola, Unidad de Investigación para la Generación y Síntesis de Evidencias en Salud, Lima, Peru
}

V1 First published: 19 Mar 2021, 10:224

https://doi.org/10.12688/f1000research.51474.1

Latest published: 19 Mar 2021, 10:224

https://doi.org/10.12688/f1000research.51474.1

\section{Abstract}

Background: Peru was one of the countries with the highest COVID19 mortality worldwide during the first stage of the pandemic. It is then relevant to evaluate the risk factors for mortality in patients hospitalized for COVID-19 in three hospitals in Peru in 2020, from March to May, 2020.

Methods: We carried out a retrospective cohort study. The population consisted of patients from three Peruvian hospitals hospitalized for a diagnosis of COVID-19 during the March-May 2020 period.

Independent sociodemographic variables, medical history, symptoms, vital functions, laboratory parameters and medical treatment were evaluated. In-hospital mortality was assessed as the outcome. We performed Cox regression models (crude and adjusted) to evaluate risk factors for in-hospital mortality. Hazard ratios (HR) with their respective $95 \%$ confidence intervals (95\% CI) were calculated. Results: We analyzed 493 hospitalized adults; $72.8 \%(n=359)$ were male and the mean age was $63.3 \pm 14.4$ years. COVID-19 symptoms appeared on average $7.9 \pm 4.0$ days before admission to the hospital, and the mean oxygen saturation on admission was $82.6 \pm$ 13.8. While $67.6 \%(n=333)$ required intensive care unit admission, only $3.3 \%(n=16)$ were admitted to this unit, and $60.2 \%(n=297)$ of the sample died. In the adjusted regression analysis, it was found that

\section{Open Peer Review Approval Status \\ 1 2 \\ version 1 \\ 19 Mar 2021

$\checkmark$
view \\ 1. José Fernando Gómez Montes, Universidad de Caldas, Manizales, Colombia \\ 2. Miguel Oswaldo Cadena Sanabria (D), Industrial University of Santander, Bucaramanga, Colombia}

Any reports and responses or comments on the article can be found at the end of the article. 
being 60 years old or older (HR=1.57; 95\% CI: 1.14-2.15), having two or more comorbidities ( $\mathrm{HR}=1.53 ; 95 \% \mathrm{CI}: 1.10-2.14)$, oxygen saturation between $85-80 \%$ (HR=2.52; 95\% CI: 1.58-4.02), less than 80\% (HR=4.59; 95\% CI: 3.01-7.00), and being in the middle (HR=1.65; 95\% CI: 1.152.39) and higher tertile (HR=2.18; 95\% CI: 1.51-3.15) of the neutrophilto-lymphocyte ratio, increased the risk of mortality.

Conclusions: The risk factors found agree with what has been described in the literature and allow the identification of vulnerable groups in whom monitoring and early identification of symptoms should be prioritized in order to reduce mortality.

\section{Keywords}

SARS-CoV-2, COVID-19, Mortality, Adults, Latin America.

\section{Q. This article is included in the Coronavirus collection.}

\section{Corresponding author: Diego Urrunaga-Pastor (diego.urrunaga.pastor1@gmail.com)}

Author roles: Díaz-Vélez C: Conceptualization, Investigation, Methodology, Writing - Original Draft Preparation, Writing - Review \& Editing; Urrunaga-Pastor D: Conceptualization, Data Curation, Formal Analysis, Methodology, Writing - Original Draft Preparation, Writing - Review \& Editing; Romero-Cerdán A: Data Curation, Investigation, Methodology, Writing - Original Draft Preparation, Writing Review \& Editing; Peña-Sánchez ER: Methodology, Writing - Original Draft Preparation, Writing - Review \& Editing; Fernández

Mogollon JL: Methodology, Writing - Original Draft Preparation, Writing - Review \& Editing; Cossio Chafloque JD: Methodology, Writing - Original Draft Preparation, Writing - Review \& Editing; Marreros Ascoy GC: Methodology, Writing - Original Draft Preparation, Writing - Review \& Editing; Benites-Zapata VA: Formal Analysis, Investigation, Methodology, Writing - Original Draft Preparation, Writing Review \& Editing

Competing interests: No competing interests were disclosed.

Grant information: The author(s) declared that no grants were involved in supporting this work.

Copyright: @ 2021 Díaz-Vélez C et al. This is an open access article distributed under the terms of the Creative Commons Attribution License, which permits unrestricted use, distribution, and reproduction in any medium, provided the original work is properly cited.

How to cite this article: Díaz-Vélez C, Urrunaga-Pastor D, Romero-Cerdán A et al. Risk factors for mortality in hospitalized patients with COVID-19 from three hospitals in Peru: a retrospective cohort study [version 1; peer review: 2 approved] F1000Research 2021, 10:224 https://doi.org/10.12688/f1000research.51474.1

First published: 19 Mar 2021, 10:224 https://doi.org/10.12688/f1000research.51474.1 


\section{Introduction}

COVID-19 is a disease characterized by severe pneumonia, and was first registered in December 2019 in Wuhan, China. ${ }^{1}$ This disease has generated great impact worldwide, especially in Latin America. ${ }^{2}$ According to the data reported by the World Health Organization (WHO), the number of COVID-19 cases at the end of December 2020 exceeded 80 million around the world, while fatal cases amount to more than 1.7 million. ${ }^{2}$ However, in regions with emerging economies or with limited access to health services such as Latin America, this disease has had great social impact. $^{3}$

It is known that approximately $80 \%$ of COVID-19 cases present a mild to moderate course; however, the remaining $20 \%$ present a severe to critical course, requiring hospital care and leading to a high risk of death. ${ }^{4}$ Thus, factors affecting the prognosis of this disease have been related to the severity of the clinical presentation and analytical markers. The analytical factors include a high neutrophil-to-lymphocyte ratio (NLR), platelet-to-lymphocyte ratio and lymphocyte-tomonocyte ratio, ${ }^{5}$ leukopenia, elevated creatinine and lactate dehydrogenase (LDH) levels and prothrombin time. ${ }^{6}$ On the other hand, demographic characteristics and medical history have been described to increase the risk of mortality due to COVID-19 and include advanced age, male sex, the presence of comorbidities, such as chronic obstructive pulmonary disease, hypertension, type 2 diabetes mellitus or coronary heart disease. ${ }^{6,7}$

Although risk factors for the disease have been described in different populations around the world, there is little scientific evidence in the Latin American population and especially in Peru, which is one of the countries with the highest mortality from COVID-19 worldwide. ${ }^{8,9}$ In addition, deficiencies in the Peruvian health system, including a scarcity of intensive care unit (ICU) beds and mechanical ventilators, as well as low compliance with government measures to combat the spread of the pandemic, could increase mortality by COVID-19. ${ }^{8,10}$ Likewise, the massive use of therapies without scientific evidence in the hospital setting, as well as the high frequency of self-medication in the Peruvian population can also aggravate the severity and mortality by COVID-19. ${ }^{11}$

Despite the government having taken measures to improve access to health services in Peru, the implementation of these strategies was slow during the first months of the pandemic. The impact of the flaws of the health system could have caused a higher mortality in the population. Taking this into account, it is relevant to explore the sociodemographic and clinical characteristics of the population hospitalized for COVID-19 in Peru and the incidence of mortality at the first stage of the pandemic. Therefore, the objective of this study was to evaluate and describe the risk factors for mortality from COVID-19 in patients from three hospitals in Peru hospitalized during the period from March to May 2020.

\section{Methods}

Design and population

We carried out a retrospective cohort study. The study population consisted of adults hospitalized during the period from March 18 to May 13, 2020 for the diagnosis of COVID-19 at the Hospital Almanzor Aguinaga Asenjo and Luis Heysen Incháustegui Hospital, located in Chiclayo and the Hospital Clínica EsSalud Chepén, located in Chepén, two cities in Peru. We included patients older than 18 years of age who were hospitalized with a diagnosis confirmed by serological or molecular tests for COVID-19, as well as suspected by a compatible clinical or radiological pattern plus an epidemiological link, despite having a non-reactive serological test for COVID-19. The exclusion criteria were patients under 18 years of age and pregnant women.

\section{Description of the study area}

The hospitals included correspond to the Lambayeque social security care network in Peru (EsSalud) and are the reference hospitals with the highest complexity for the management of patients with COVID-19. From the first confirmed case of COVID-19 in Lambayeque in March 2020 until November 30, 2020, there was a total of 18,570 confirmed cases of COVID-19, 5,654 hospitalized cases and 2,579 deaths.

Type of sampling and sample size calculation

The sampling was non-probabilistic and we included all participants hospitalized during the study period who met the inclusion criteria.

\section{Procedures}

The information on the participants included in the study was collected by two researchers from the EsSalud virtual medical records registry. The collection of all records was carried out independently by each of the data entry operators, to ensure adequate data collection and reduce erroneous records. Sociodemographic variables, medical history and laboratory markers were collected from hospitalized patients during the period from March 18 to May 13, 2020. Laboratory markers 
were collected during the first 24 hours of hospitalization. Mortality follow-up was in-hospital and the date of hospital admission was considered as the start of follow-up. The information was tabulated in a Microsoft Excel 2016 document, and quality control of the data was carried out by a researcher of our team.

\section{Bias}

This study included participants insured by Peruvian social security, who have socioeconomic characteristics that could differ from the national population; however, this study is one of the first reports carried out in Peru, ${ }^{12,53}$ one of the countries with the highest mortality rates during the first wave of the pandemic. In addition, certain laboratory markers had a significant percentage of missing values, however, we included in the multivariate analysis the most relevant markers for the association of interest.

\section{Variables}

Outcome variable: In-hospital mortality

Mortality in hospitalized patients with a confirmed or probable diagnosis of COVID-19 was evaluated as an outcome variable. This was collected according to outcome recorded in the clinical history at the end of the follow-up (June 2, 2020).

Exposure variables

Sociodemographic variables

The demographic characteristics recorded were: age $(<50,50-59, \geq 60$ years), sex (female, male), comorbidities (obesity, type 2 diabetes mellitus, hypertension, asthma, cancer, chronic kidney disease). Likewise, we generated a variable that grouped these comorbidities into different categories $(0,1,2$ or more).

Symptoms and epidemiological link

The time of disease of the patients (in days), symptoms (respiratory distress, cough, fever, sore throat, diarrhea, headache, nasal congestion, anosmia, ageusia) were included. In addition, contact with a confirmed case of COVID-19 (yes, no) was considered.

Baseline vital functions

Baseline vital function values were collected at admission, including temperature, respiratory rate, heart rate, and oxygen saturation.

Baseline auxiliary exams

The following laboratory values were considered: hemoglobin (g/dL), leukocytes (leukocytosis was defined as a value greater than or equal to 10,000 cells $/ \mathrm{mm}^{3}$ ), neutrophils (cells $/ \mathrm{mm}^{3}$ ), lymphocytes (lymphopenia was defined as a value less than 0.8 cells $/ \mathrm{mm}^{3}$ ), the NLR (categorized into tertiles), platelets (thrombocytopenia was defined as a value less than 150,000 cells $\left./ \mathrm{mm}^{3}\right)$, creatinine $(\mathrm{mg} / \mathrm{dL})$, urea $(\mathrm{mg} / \mathrm{dL})$, aspartate transaminase (AST) $(\mathrm{U} / \mathrm{L})$, alanine aminotransferase (ALT) (U/L), and LDH (U/L).

Treatment received

The treatment administered to hospitalized patients was included, considering antibiotic therapy (azithromycin, cephalosporins, carbapenems, among others), corticosteroid therapy (methylprednisolone, dexamethasone, hydrocortisone, prednisone), antiparasitic drugs (hydroxychloroquine, ivermectin), anticoagulants (enoxaparin) and antivirals (lopinavir)/ritonavir).

\section{Statistical analysis}

The descriptive results of the categorical variables were presented using absolute and relative frequencies, while quantitative variables are shown using central tendency and dispersion measures. The comparison of proportions between the categorical covariates and the outcome was performed using the Chi-square test, while the Student's t test or Mann Whitney U test was used to evaluate differences with numerical covariates. 
The Kaplan-Meier method was used to describe the survival function, and the log-rank test was used for the crude comparison of survival functions. A Cox regression analysis (crude and adjusted) was performed to evaluate independent risk factors for mortality in the study sample. The adjusted model included variables the association of which has been described in the literature. ${ }^{6,12}$ Crude and adjusted hazard ratios (HR) were calculated with their respective $95 \%$ confidence intervals $(95 \% \mathrm{CI})$. Compliance with the proportionality of hazards assumption of the Cox model was verified and collinearity relationships were evaluated in the adjusted model. All analyses were conducted with the statistical package STATA v14.0.

\section{Ethical aspects}

This study was carried out following the guidelines of the Declaration of Helsinki of 1964 and its subsequent amendments. The virtual medical records were reviewed without affecting the social, psychological and physical integrity of the study participants. We did not request the signing of an informed consent because the data was anonymized and we did not violate the integrity of the participant. In addition, this study was evaluated and approved by the Research Ethics Committee for COVID-19 of EsSalud, Peru (N²4-IETSI-ESSALUD-2020).

\section{Results}

Descriptive and bivariate analyses according to mortality in the study sample.

A total of 493 hospitalized adults were analyzed, $72.8 \%(n=359)$ of whom were male with a mean age of $63.3 \pm$ 14.4 years. Likewise, $62.5 \%(n=308)$ were 60 years of age or older, $25 \%(n=123)$ had hypertension, and $16.5 \%(n=81)$ were obese. The median length of hospital stay was five days (IQR: 3-9), and symptoms appeared on average $7.9 \pm$ 4.0 days before admission to the hospital, the most common being respiratory distress, followed by cough and fever, while only $3.7 \%(n=18)$ reported having had contact with a confirmed case of COVID-19. Likewise, the mean oxygen saturation upon hospital admission was $82.6 \pm 13.8 ; 83.8 \%(n=413)$ of the cases were confirmed, but only $3.4 \%(n=14)$ of the confirmed cases were diagnosed by a real-time polymerase chain reaction (RT-PCR) test. $61.1 \%(n=258)$ of the participants had leukocytosis, and 39.6\% $(n=167)$ had lymphopenia. While 67.6\% $(n=333)$ required ICU admission, only $3.3 \%(n=16)$ were actually admitted to this unit, and $60.2 \%(n=297)$ of the sample died. In addition, there were 1.99 deaths per 100 person-days at risk. Table 1 shows the bivariate analysis of the study variables and mortality.

\section{Treatment received by the study participants}

Antibiotic therapy was administered to $98.8 \%(\mathrm{n}=487)$ of the participants, including a combination of azithromycin + cephalosporins in $78.2 \%(n=381)$. Likewise, $65.7 \%(n=324)$ of the participants received corticosteroid treatment, with methylprednisolone being the preferred treatment in $64.8 \%(\mathrm{n}=210)$, followed by dexamethasone with $27.2 \%(\mathrm{n}=88)$. Additionally, $76.7 \%(\mathrm{n}=378)$ of the sample received hydroxychloroquine, and $26.0 \%(\mathrm{n}=128)$ received ivermectin, while $79.3 \%(n=391)$ were prescribed enoxaparin. Likewise, in the bivariate analysis, statistically significant differences were found between the types of corticosteroids received, having received enoxaparin, and mortality (Table 2).

\section{Survival estimated using Kaplan-Meier curves}

A better survival curve was found in participants admitted to hospital with a higher oxygen saturation ( $\geq 92 \%$ vs. $91-86 \%$ vs. $85-80 \%$ vs. $<80 \%$ ), which was statistically significant $(\mathrm{p}<0.001)$ (Figure 1). Likewise, the survival curve was better in younger patients ( $<50$ years vs. $50-59$ vs. $\geq 60)$ and in those who received dexamethasone (dexamethasone vs. others) during hospitalization (Figures 2 and 3). These differences were statistically significant $(\mathrm{p}<0.001)$.

\section{Risk factors for mortality in hospitalized COVID-19 patients in the study sample}

In the crude Cox regression analysis, it was found that age greater than or equal to 60 years (crude hazard ratio [cHR] $=2.52$; 95\% CI: 1.93-3.28), having two or more comorbidities (cHR=1.59; 95\% CI: 1.19-2.12), oxygen saturation between $85-80 \%(\mathrm{cHR}=2.70$; $95 \%$ CI: $1.81-4.04)$ or less than $80 \%$ (cHR=5.25; 95\% CI: 3.69-7.46), as well as the intermediate $(\mathrm{cHR}=2.16 ; 95 \% \mathrm{CI}: 1.52-3.07)$ and high NLR tertile (cHR=3.40; 95\% CI: 2.42-4.78) were associated with a higher risk of mortality in hospitalized COVID-19 patients in Peru. In the adjusted regression analysis, age greater than or equal to 60 years (adjusted hazard ratio $[\mathrm{aHR}]=1.57$; 95\% CI: 1.14-2.15), having two or more comorbidities $(\mathrm{aHR}=1.53$; 95\% CI: 1.10-2.14), oxygen saturation between $85-80 \%$ (aHR=2.52; 95\% CI: 1.58-4.02), less than $80 \%$ $(\mathrm{aHR}=4.59 ; 95 \% \mathrm{CI}: 3.01-7.00)$, as well as being in the intermediate $(\mathrm{aHR}=1.65 ; 95 \% \mathrm{CI}: 1.15-2.39)$ and higher tertile NLR (aHR=2.18; 95\% CI: 1.51-3.15) remained associated with a higher risk of mortality (Table 3 ).

\section{Discussion}

\section{Main results}

This study included 493 patients hospitalized in three hospitals in Peru. We found that approximately six out of 10 patients died during follow-up, and while about seven out of 10 required admission to the ICU, only $3.3 \%$ were actually admitted to this unit. In addition, it was found that being an older adult, having an oxygen saturation level of 


\begin{tabular}{|c|c|c|c|c|c|c|}
\hline \multirow[t]{3}{*}{ Variables } & \multirow[t]{3}{*}{$\mathbf{n}$} & \multirow[t]{3}{*}{$\%$} & \multirow[t]{3}{*}{ mean \pm SD $^{1}$} & \multicolumn{2}{|c|}{ In-hospital death } & \multirow{3}{*}{ P value } \\
\hline & & & & \multirow{2}{*}{$\begin{array}{l}\text { Survivor } \\
n=196 \\
(39.8 \%)\end{array}$} & Non-survivor & \\
\hline & & & & & $\begin{array}{l}n=297 \\
(60.2 \%)\end{array}$ & \\
\hline \multicolumn{7}{|l|}{$\begin{array}{l}\text { Demographic } \\
\text { characteristics }\end{array}$} \\
\hline Age & & & $63.3 \pm 14.4$ & $56.4 \pm 13.4$ & $67.9 \pm 13.1$ & $<0.001$ \\
\hline$<50$ years & 85 & 17.2 & & $58(68.2)$ & $27(31.8)$ & $<0.001$ \\
\hline 50-59 years & 100 & 20.3 & & $54(54.0)$ & $46(46.0)$ & \\
\hline$\geq 60$ years & 308 & 62.5 & & $84(27.3)$ & $224(72.7)$ & \\
\hline Sex & & & & & & 0.638 \\
\hline Female & 134 & 27.2 & & $51(38.1)$ & $83(61.9)$ & \\
\hline Male & 359 & 72.8 & & $145(40.4)$ & $214(59.6)$ & \\
\hline Comorbidities & & & & & & $<0.001$ \\
\hline 0 & 267 & 54.2 & & $115(43.1)$ & $152(56.9)$ & \\
\hline 1 & 143 & 29.0 & & $63(44.1)$ & $80(55.9)$ & \\
\hline 2 or more & 83 & 16.8 & & $18(21.7)$ & 65 (78.3) & \\
\hline Obesity & 81 & 16.5 & & $28(34.6)$ & $53(65.4)$ & 0.297 \\
\hline Type 2 diabetes mellitus & 91 & 18.5 & & $31(34.1)$ & $60(65.9)$ & 0.219 \\
\hline Hypertension & 123 & 25.0 & & 39 (31.7) & $84(68.3)$ & 0.035 \\
\hline Asthma & 14 & 2.8 & & $5(35.7)$ & $9(64.3)$ & 0.754 \\
\hline Cancer & 11 & 2.2 & & $3(27.3)$ & $8(72.7)$ & 0.539 \\
\hline Chronic kidney disease & 10 & 2.0 & & $2(20.0)$ & $8(80.0)$ & 0.328 \\
\hline \multicolumn{7}{|l|}{$\begin{array}{l}\text { Symptoms and } \\
\text { epidemiological link }\end{array}$} \\
\hline Time of disease $(n=405)$ & & & $7(5-10)$ & $7(6-10)$ & $7(5-10)$ & 0.295 \\
\hline \multicolumn{7}{|l|}{ Symptoms ( $n=450)$} \\
\hline Breathing distress & 407 & 90.4 & & $165(40.5)$ & $242(59.5)$ & 0.449 \\
\hline Cough & 357 & 79.3 & & $148(41.5)$ & $209(58.5)$ & 0.770 \\
\hline Fever & 246 & 54.7 & & $104(42.3)$ & $142(57.7)$ & 0.581 \\
\hline Sore throat & 48 & 10.7 & & $22(45.8)$ & $26(54.2)$ & 0.482 \\
\hline Diarrhea & 40 & 8.9 & & $21(52.5)$ & $19(47.5)$ & 0.125 \\
\hline Headache & 30 & 6.7 & & $15(50.0)$ & $15(50.0)$ & 0.306 \\
\hline Nasal congestion & 9 & 2.0 & & $2(22.2)$ & $7(77.8)$ & 0.319 \\
\hline Anosmia & 3 & 0.7 & & $2(66.7)$ & $1(33.3)$ & 0.571 \\
\hline Ageusia & 2 & 0.4 & & $1(50.0)$ & $1(50.0)$ & 1.000 \\
\hline \multicolumn{7}{|l|}{$\begin{array}{l}\text { Contact with a confirmed } \\
\text { case of COVID-19 }\end{array}$} \\
\hline Yes & 18 & 3.7 & & 7 (38.9) & $11(61.1)$ & 0.939 \\
\hline \multicolumn{7}{|l|}{ Baseline vital functions } \\
\hline Temperature $\left({ }^{\circ} \mathrm{C}\right)(\mathrm{n}=284)$ & & & $36.8(36.6-37.2)$ & $36.8(36.6-37.4)$ & $36.8(36.5-37.0)$ & 0.299 \\
\hline Fever $\left(\geq 38^{\circ} \mathrm{C}\right)$ & 30 & 10.6 & & $16(53.3)$ & $14(46.7)$ & 0.476 \\
\hline Respiratory rate $(n=402)$ & & & $26(22-31)$ & $24(22-28)$ & $28(24-32)$ & $<0.001$ \\
\hline Tachypnea, $\geq 22$ & 334 & 83.1 & & $132(39.5)$ & $202(60.5)$ & 0.023 \\
\hline Tachypnea, $\geq 30$ & 136 & 33.8 & & $34(25.0)$ & $102(75.0)$ & $<0.001$ \\
\hline
\end{tabular}


Table 1. Continued

\begin{tabular}{|c|c|c|c|c|c|c|}
\hline \multirow[t]{3}{*}{ Variables } & \multirow[t]{3}{*}{$\mathbf{n}$} & \multirow[t]{3}{*}{$\%$} & \multirow[t]{3}{*}{ mean $\pm S^{1}$} & \multicolumn{2}{|c|}{ In-hospital death } & \multirow{3}{*}{ P value } \\
\hline & & & & \multirow{2}{*}{$\begin{array}{l}\text { Survivor } \\
n=196 \\
(39.8 \%)\end{array}$} & Non-survivor & \\
\hline & & & & & $\begin{array}{l}n=297 \\
(60.2 \%)\end{array}$ & \\
\hline Heart rate $(n=467)$ & & & $91(82-108)$ & $88(80-100)$ & $95(84-110)$ & $<0.001$ \\
\hline Tachycardia, $\geq 100$ & 176 & 37.7 & & $49(27.8)$ & $127(72.2)$ & $<0.001$ \\
\hline Tachycardia, $\geq 120$ & 46 & 9.9 & & $10(21.7)$ & 36 (78.3) & 0.008 \\
\hline $\begin{array}{l}\text { Oxygen saturation, } \% \\
(n=470)\end{array}$ & & & $88(78-92)$ & $90(87-93)$ & $82.5(70-89.5)$ & $<0.001$ \\
\hline$<96 \%$ & 432 & 91.9 & & 165 (38.2) & $267(61.8)$ & 0.001 \\
\hline$<94 \%$ & 403 & 85.7 & & $143(35.5)$ & $260(64.5)$ & $<0.001$ \\
\hline$<92 \%$ & 347 & 73.8 & & $111(32.0)$ & $236(68.0)$ & $<0.001$ \\
\hline$<90 \%$ & 278 & 59.2 & & $68(24.5)$ & $210(75.5)$ & $<0.001$ \\
\hline$<85 \%$ & 181 & 38.5 & & $23(12.7)$ & $158(87.3)$ & $<0.001$ \\
\hline$<80 \%$ & 125 & 26.6 & & $11(8.8)$ & $114(91.2)$ & $<0.001$ \\
\hline \multicolumn{7}{|l|}{$\begin{array}{l}\text { Case definition and } \\
\text { diagnosis }\end{array}$} \\
\hline Positive diagnosis $(n=413)$ & & & & & & 0.547 \\
\hline $\begin{array}{l}\text { Rapid serological test } \\
\text { positive to IgG }\end{array}$ & 19 & 4.6 & & $7(36.8)$ & $12(63.2)$ & \\
\hline $\begin{array}{l}\text { Rapid serological test } \\
\text { positive to IgM/IgG }\end{array}$ & 343 & 83.0 & & $139(40.5)$ & $204(59.5)$ & \\
\hline $\begin{array}{l}\text { Rapid serological test } \\
\text { positive to IgM }\end{array}$ & 37 & 9.0 & & $15(40.5)$ & $22(59.5)$ & \\
\hline RT-PCR & 14 & 3.4 & & $3(21.4)$ & $11(78.6)$ & \\
\hline Case definition & & & & & & 0.961 \\
\hline Suspicious & 80 & 16.2 & & $32(40.0)$ & $48(60.0)$ & \\
\hline Confirmed & 413 & 83.8 & & $164(39.7)$ & $249(60.3)$ & \\
\hline \multicolumn{7}{|l|}{ Baseline auxiliary exams } \\
\hline Hemoglobin, g/dL (n=333) & & & $13.4(12.4-14.3)$ & $13.8(12.6-14.6)$ & $13.3(12.3-14.1)$ & 0.0198 \\
\hline $\begin{array}{l}\text { Leukocytes, cells } / \mathrm{mm}^{\wedge} 3 \\
(\mathrm{n}=422)\end{array}$ & & & $11.6(8.3-15.6)$ & $9.1(6.9-12.6)$ & $13.0(9.9-17.5)$ & $<0.001$ \\
\hline $\begin{array}{l}\text { Leukocytosis ( } \geq 10,000 \\
\text { cells } / \mathrm{mm}^{\wedge} 3 \text { ) }\end{array}$ & 258 & 61.1 & & $77(29.8)$ & $181(70.2)$ & $<0.001$ \\
\hline $\begin{array}{l}\text { Neutrophils, cells } / \mathrm{mm}^{\wedge} 3 \\
(\mathrm{n}=422)\end{array}$ & & & $9.6(6.8-14.0)$ & $7.5(5.3-11.1)$ & 111 & $<0.001$ \\
\hline $\begin{array}{l}\text { Lymphocytes, cells } / \mathrm{mm}^{\wedge} 3 \\
(\mathrm{n}=422)\end{array}$ & & & $0.92(0.6-1.3)$ & $1.0(0.7-1.4)$ & $0.8(0.6-1.2)$ & $<0.001$ \\
\hline $\begin{array}{l}\text { Lymphopenia ( }<0.8 \text { cells/ } \\
\mathrm{mm}^{\wedge} 3 \text { ) }\end{array}$ & 167 & 39.6 & & $51(30.5)$ & $116(69.5)$ & $<0.001$ \\
\hline $\operatorname{NLR}(n=422)$ & & & $11(6.5-18.2)$ & $7.7(4.6-12.7)$ & $12.9(8.7-23.3)$ & $<0.001$ \\
\hline Low tertile & 141 & 33.4 & $4.9(3.5-6.5)$ & $92(65.3)$ & 49 (34.7) & $<0.001$ \\
\hline Intermediate tertile & 141 & 33.4 & $11(9.4-12.6)$ & $56(39.7)$ & $85(60.3)$ & \\
\hline High tertile & 140 & 33.2 & $23.5(18.2-31.7)$ & $32(22.9)$ & $108(77.1)$ & \\
\hline $\begin{array}{l}\text { Platelets, cells } / \mathrm{mm}^{\wedge} 3 \\
(\mathrm{n}=422)\end{array}$ & & & $286.1 \pm 124.2$ & $295.1 \pm 125.2$ & $279.3 \pm 123.2$ & 0.196 \\
\hline $\begin{array}{l}\text { Thrombocytopenia } \\
\left(<150,000 \text { cells } / \mathrm{mm}^{\wedge} 3\right)\end{array}$ & 47 & 11.1 & & $17(36.2)$ & $30(63.8)$ & 0.340 \\
\hline Creatinine, mg/dL ( $n=350)$ & & & $0.74(0.59-0.92)$ & $0.71(0.57-0.84)$ & $0.75(0.60-0.97)$ & 0.025 \\
\hline
\end{tabular}


Table 1. Continued

\begin{tabular}{|c|c|c|c|c|c|c|}
\hline \multirow[t]{3}{*}{ Variables } & \multirow[t]{3}{*}{$\mathbf{n}$} & \multirow[t]{3}{*}{$\%$} & \multirow[t]{3}{*}{ mean \pm SD $^{1}$} & \multicolumn{2}{|c|}{ In-hospital death } & \multirow{3}{*}{ P value } \\
\hline & & & & \multirow{2}{*}{$\begin{array}{l}\text { Survivor } \\
n=196 \\
(39.8 \%)\end{array}$} & Non-survivor & \\
\hline & & & & & $\begin{array}{l}n=297 \\
(60.2 \%)\end{array}$ & \\
\hline Urea, mg/dL (n=189) & & & $39.2(28.0-53.0)$ & $36.5(27.2-45.8)$ & $46.6(30.3-71.0)$ & $<0.001$ \\
\hline AST, U/L ( $n=195)$ & & & $41.0(30.0-58.9)$ & $40(27-57)$ & $42.2(32.0-58.9)$ & 0.262 \\
\hline ALT, U/L (n=203) & & & $42(26-73)$ & $50.3(24.4-81.0)$ & $39.9(26.7-61.0)$ & 0.259 \\
\hline $\mathrm{LDH}, \mathrm{U} / \mathrm{L}(\mathrm{n}=166)$ & & & $403(302-530)$ & $302(225-367)$ & $484(409-697)$ & $<0.001$ \\
\hline $\mathrm{LDH} \geq 245 \mathrm{U} / \mathrm{L}$ & 146 & 88.0 & & $50(34.3)$ & $96(65.8)$ & $<0.001$ \\
\hline $\mathrm{LDH} \geq 450 \mathrm{U} / \mathrm{L}$ & 69 & 41.6 & & $4(5.8)$ & $65(94.2)$ & $<0.001$ \\
\hline \multicolumn{7}{|l|}{ Time } \\
\hline Hospital stay length, days & & & $5(3-9)$ & $8(5-11)$ & $3(2-6)$ & $<0.001$ \\
\hline \multicolumn{7}{|l|}{ Outcomes } \\
\hline Admitted to ICU & 16 & 3.3 & & $3(18.8)$ & $13(81.3)$ & 0.081 \\
\hline $\begin{array}{l}\text { High Flow oxygen } \\
\text { requirement (FiO2 } \geq 0.36 \text { ) }\end{array}$ & 350 & 71.0 & & $60(17.1)$ & $290(82.7)$ & $<0.001$ \\
\hline $\begin{array}{l}\text { ICU requirement (FiO2 } \\
\geq 0.80)\end{array}$ & 333 & 67.5 & & $47(14.1)$ & $286(85.9)$ & $<0.001$ \\
\hline
\end{tabular}

Data expressed as mean \pm standard deviation, median (interquartile range) or number (percentage). ${ }^{1}$ SD: Standard deviation.AST: aspartate transaminase; ALT: alanine aminotransferase; LDH: lactate dehydrogenase; ICU: intensive care unit; RT-PCT: real-time polymerase chain reaction; NLR: neutrophil-to-lymphocyte ratio.HR: Hazard ratio; cHR: crude hazard ratio; aHR: adjusted hazard ratio; $95 \%$ CI: 95\% confidence interval; NLR: neutrophil-to-lymphocyte ratio.

$85 \%$ or less at admission, and having a high NLR value were associated with a higher risk of mortality. In addition, approximately eight out of 10 hospitalized patients received hydroxychloroquine and nine out of 10 were prescribed azithromycin.

It was found that about six in 10 hospitalized patients died, which is a high frequency compared to the $28.3 \%, 21.7 \%$ and $14.6 \%$ reported in patients hospitalized for COVID-19 from Wuhan, ${ }^{6}$ New York ${ }^{13}$ and Madrid, ${ }^{14}$ respectively. Likewise, the mortality found in this study was higher than the $39.6 \%$ and $38 \%$ described in studies carried out in Brazil ${ }^{15}$ and Mexico, ${ }^{16}$ respectively. This could be due to patients having received hospital care on average 7.9 days after the onset of symptoms, with a subsequently higher risk of severe disease and mortality. Likewise, it was of note that $73.8 \%$ of the patients arrived at the hospital with an oxygen saturation lower than $92 \%$, hypoxia being a risk factor for mortality. ${ }^{17}$ On the other hand, despite $67.5 \%$ of the patients requiring admission to the ICU, only $3.3 \%$ were actually admitted, which could explain the high mortality and the shorter hospital stay in the group that died. In the present study, approximately $25 \%$ of the deaths occurred within the first 24 hours of hospitalization, suggesting that the population arrived late to medical care and adequate early monitoring of symptoms, which could avoid complications, was not carried out. ${ }^{18}$

In this study, older adults were found to have a higher risk of mortality. This situation is consistent with what has been described in previous studies, ${ }^{6,19}$ and could be explained by greater dysregulation of immune function and immunosenescence in older adults, as well as a higher prevalence of comorbidities ${ }^{20}$ Certain comorbidities, such as hypertension, diabetes mellitus and chronic kidney disease, are treated with angiotensin converting enzyme inhibitors and angiotensin II receptor blockers, increasing the risk of severe disease and mortality. ${ }^{19}$ However, the role of the immune system in the pathophysiology of COVID-19 in this age group is still under study.

Furthermore, elevated NLR values were found to be associated with an increased risk of mortality. Inflammation plays a relevant role in the pathophysiology of COVID-19 and allows establishing the prognosis of patients. Within the response of the innate immune system to a respiratory infection, there is a proliferation of neutrophils at the alveolar level, which could generate collateral damage and cytotoxicity. Furthermore, the release of anti-inflammatory cytokines could lead to lymphocyte apoptosis, producing lymphocytopenia. ${ }^{21,22}$ In this way, an elevated NLR has been described as an indicator of severe inflammation progression, which could lead to complications such as sepsis, multi-organ failure, and acute respiratory distress syndrome. ${ }^{23}$ In previous studies, it has been described as a prognostic marker for COVID-19, and its usefulness is highlighted due to its low cost, easy implementation and practicality. ${ }^{24}$ 
Table 2. Descriptive and bivariate analysis of the treatment received according to in-hospital death in the study sample.

\begin{tabular}{|c|c|c|c|c|c|}
\hline \multirow[t]{3}{*}{ Variables } & \multirow[t]{3}{*}{$\mathbf{n}$} & \multirow[t]{3}{*}{$\%$} & \multicolumn{2}{|c|}{ In-hospital death } & \multirow{3}{*}{ P value } \\
\hline & & & \multirow{2}{*}{$\begin{array}{l}\text { Survivor } \\
\mathbf{n = 1 9 6} \\
(39.8 \%)\end{array}$} & Non-survivor & \\
\hline & & & & $\begin{array}{l}n=297 \\
(60.2 \%)\end{array}$ & \\
\hline Received antibiotic therapy & & & & & 0.686 \\
\hline No & 6 & 1.2 & $3(50.0)$ & $3(50.0)$ & \\
\hline Yes & 487 & 98.8 & $193(39.6)$ & $294(60.4)$ & \\
\hline Types of antibiotic therapy & & & & & 0.919 \\
\hline Azithromycin+ Cephalosporins & 381 & 78.2 & $151(39.6)$ & $230(60.4)$ & \\
\hline Azithromycin & 45 & 9.3 & $20(44.4)$ & $25(55.6)$ & \\
\hline Cephalosporins & 26 & 5.3 & $10(38.5)$ & $16(61.5)$ & \\
\hline Azithromycin + Carbapenems & 23 & 4.7 & $7(30.4)$ & $16(69.6)$ & \\
\hline Carbapenems & 6 & 1.2 & $3(50.0)$ & $3(50.0)$ & \\
\hline Azithromycin + others & 4 & 0.8 & $1(25.0)$ & $3(75.0)$ & \\
\hline Others & 2 & 0.4 & $1(50.0)$ & $1(50.0)$ & \\
\hline Received corticosteroids & & & & & 0.971 \\
\hline No & 169 & 34.3 & 67 (39.6) & $102(60.4)$ & \\
\hline Yes & 324 & 65.7 & $129(39.8)$ & $195(60.2)$ & \\
\hline Type of corticosteroids & & & & & $<0.001$ \\
\hline Methylprednisolone & 210 & 64.8 & $72(34.3)$ & $138(65.7)$ & \\
\hline Dexamethasone & 88 & 27.2 & $48(54.6)$ & $40(45.4)$ & \\
\hline Hydrocortisone & 21 & 6.5 & $4(19.1)$ & $17(80.9)$ & \\
\hline Prednisone & 5 & 1.5 & $5(100.0)$ & $0(0.0)$ & \\
\hline Received hydroxychloroquine & & & & & 0.554 \\
\hline No & 115 & 23.3 & $43(37.4)$ & $72(62.6)$ & \\
\hline Yes & 378 & 76.7 & $153(40.5)$ & $225(59.5)$ & \\
\hline Received ivermectin & & & & & 0.283 \\
\hline No & 365 & 74.0 & $140(38.4)$ & $225(61.6)$ & \\
\hline Yes & 128 & 26.0 & $56(43.8)$ & $72(56.2)$ & \\
\hline Received enoxaparin & & & & & $<0.001$ \\
\hline No & 102 & 20.7 & 55 (53.9) & $47(46.1)$ & \\
\hline Yes & 391 & 79.3 & $141(36.1)$ & $250(63.9)$ & \\
\hline Received Lopinavir/Ritonavir & & & & & 0.283 \\
\hline No & 367 & 74.4 & $151(41.1)$ & $216(58.9)$ & \\
\hline Yes & 126 & 25.6 & $45(35.7)$ & $81(64.3)$ & \\
\hline
\end{tabular}

Hypoxemia was found to be a risk factor for mortality in the study sample, which is similar to results in previous studies. ${ }^{25,26}$ Approximately four out of 10 hospitalized patients arrived at the hospital with oxygen saturation lower than $86 \%$, indicating that these patients arrived late at the hospital and correlates with the mean time of disease onset that exceeded seven days. Thus, the high proportion of patients with hypoxemia could be associated with the high mortality in the sample. Likewise, patients who arrive at the hospital with a higher degree of hypoxia require more intensive care, oxygen support, access to the ICU and mechanical ventilation, ${ }^{17}$ which in Peru is limited ${ }^{27}$ and could explain the high incidence of mortality. It should be noted that hypoxia has been associated with inflammation, which with the proliferation and elevation of cytokine levels, increases the already established lung damage and worsens the prognosis. $^{28}$ 


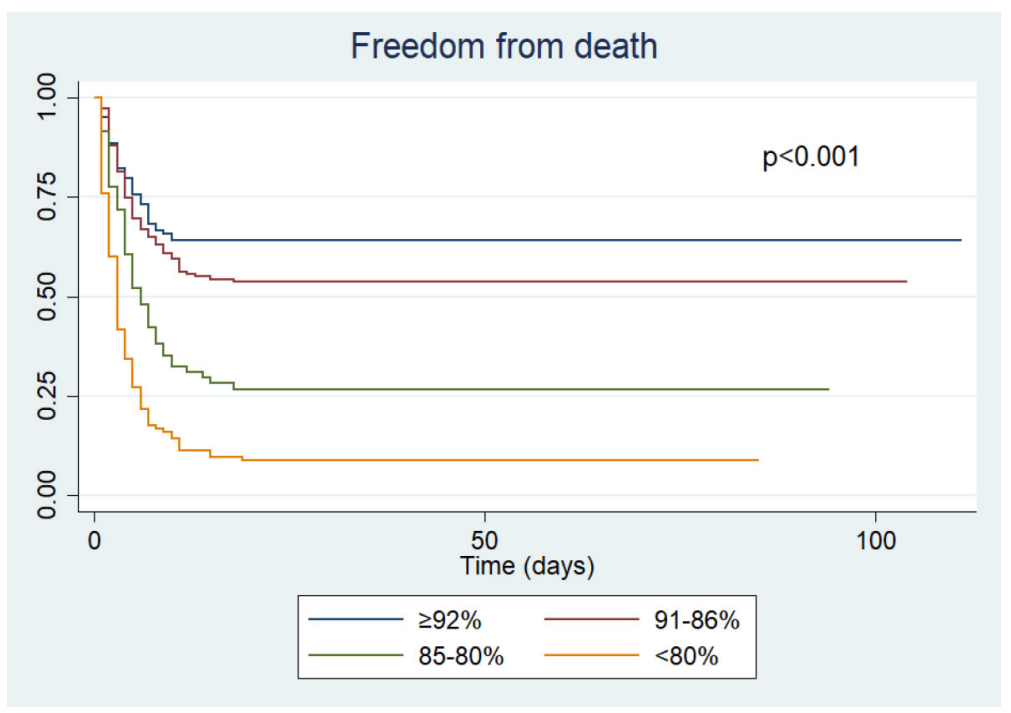

Figure 1. Survival analysis by oxygen saturation level at hospital admission.

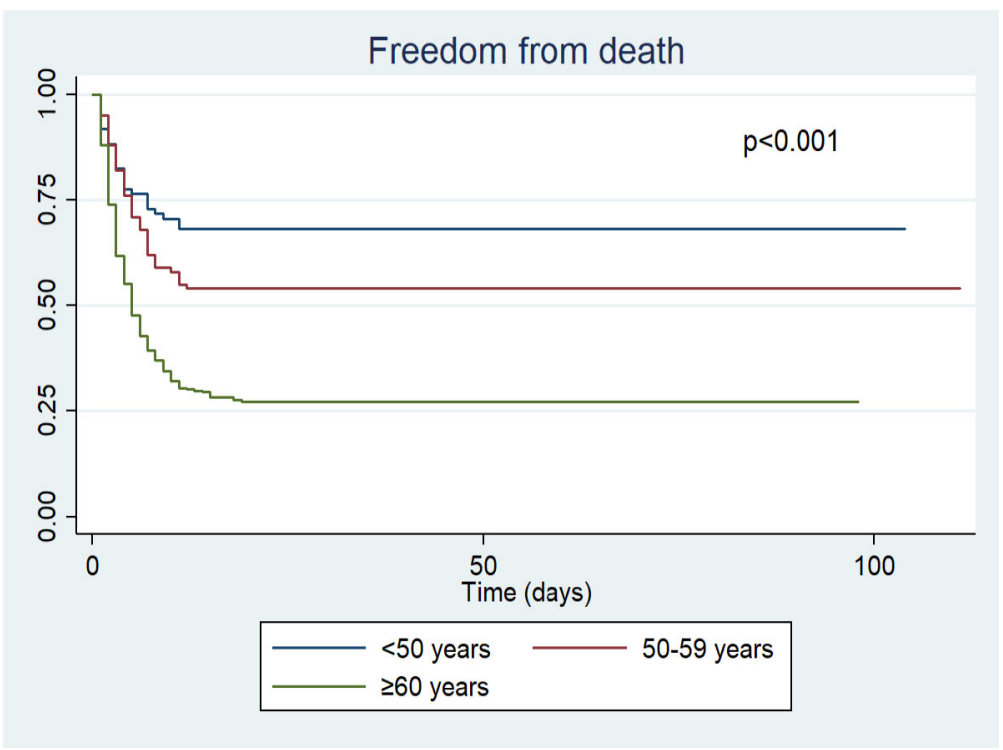

Figure 2. Survival analysis by age groups of the participants.

We found an association between having two or more comorbidities and a higher risk of mortality. The main comorbidities in the population were hypertension, diabetes mellitus and obesity, which have been described as predictors of severity and worse prognosis in previous studies. ${ }^{29-31}$ The pro-inflammatory role of obesity has been mentioned, which induces diabetes mellitus and oxidative stress, affecting cardiovascular function. ${ }^{32}$ Likewise, a greater abdominal circumference increases breathing difficulty, which can restrict ventilation by decreasing the excursion of the diaphragm. ${ }^{33}$ It should be noted that diabetes mellitus and obesity alter immune response to viral infections. ${ }^{33}$

Nearly all of the participants received antibiotic therapy, the main drug being azithromycin. However, less than $7 \%$ of patients hospitalized for COVID-19 were reported as having bacterial coinfection. ${ }^{34}$ Likewise, the use of azithromycin in conjunction with hydroxychloroquine gained relevance based on initial favorable reports in March $2020,{ }^{35}$ both drugs being approved for use in Peru as of April 2020. ${ }^{36}$ However, later, the use of these drugs was rejected internationally, due to their null positive effect ${ }^{37,38}$ and the increased risk of mortality. ${ }^{39}$ On the other hand, another drug frequently used was ivermectin, which began to gain relevance within the scheme of the Ministry of Health of Peru (MINSA) due to an in vitro study published during the study period. ${ }^{40}$ However, this drug was consolidated in Peru over the following months after 


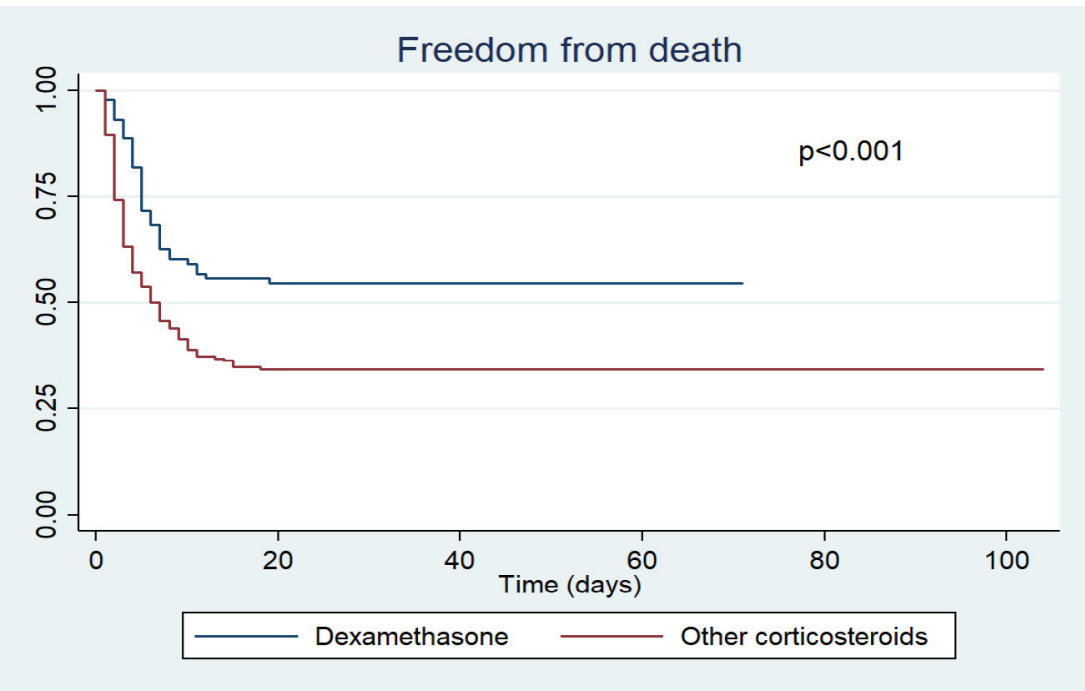

Figure 3. Survival analysis by group of corticosteroids received.

Table 3. Cox regression analysis to evaluate risk factors of mortality in the study sample.

\begin{tabular}{|c|c|c|c|c|}
\hline \multirow[t]{2}{*}{ Variables } & \multicolumn{2}{|l|}{ Crude model } & \multicolumn{2}{|l|}{ Adjusted model } \\
\hline & cHR $(95 \%$ CI) & P value & $\operatorname{aHR}(95 \% \mathrm{CI})$ & P value \\
\hline \multicolumn{5}{|l|}{ Age } \\
\hline$\geq 60$ years & $2.52(1.93-3.28)$ & $<0.001$ & $1.57(1.14-2.15)$ & 0.006 \\
\hline \multicolumn{5}{|l|}{ Sex } \\
\hline Female & Reference & & Reference & \\
\hline Male & $0.94(0.73-1.21)$ & 0.645 & $1.05(0.77-1.42)$ & 0.756 \\
\hline \multicolumn{5}{|l|}{ Comorbidities } \\
\hline 0 & Reference & & Reference & \\
\hline 1 & $0.92(0.70-1.21)$ & 0.559 & $0.92(0.67-1.26)$ & 0.602 \\
\hline 2 or more & $1.59(1.19-2.12)$ & 0.002 & $1.53(1.10-2.14)$ & 0.011 \\
\hline \multicolumn{5}{|l|}{ Oxygen saturation } \\
\hline$\geq 92 \%$ & Reference & & Reference & \\
\hline $91-86 \%$ & $1.35(0.93-1.97)$ & 0.116 & $1.18(0.75-1.84)$ & 0.474 \\
\hline $85-80 \%$ & $2.70(1.81-4.04)$ & $<0.001$ & $2.52(1.58-4.02)$ & $<0.001$ \\
\hline$<80 \%$ & $5.25(3.69-7.46)$ & $<0.001$ & $4.59(3.01-7.00)$ & $<0.001$ \\
\hline \multicolumn{5}{|l|}{ NLR tertiles } \\
\hline Low tertile & Reference & & Reference & \\
\hline Intermediate tertile & $2.16(1.52-3.07)$ & $<0.001$ & $1.65(1.15-2.39)$ & 0.007 \\
\hline High tertile & $3.40(2.42-4.78)$ & $<0.001$ & $2.18(1.51-3.15)$ & $<0.001$ \\
\hline
\end{tabular}

promoting its use through self-medication ${ }^{41}$ and even subdermal application. ${ }^{42}$ The use of these medical therapies based on studies with biases or design flaws ${ }^{35,43}$ could have caused people to have false security and to have not gone to the hospital on the appearance of symptoms, thereby leading to disease progression and an increased risk of death or the development of severe illness. On the other hand, corticosteroids were administered in two out of three people, with a predominance of methylprednisolone, while dexamethasone, which was reported to reduce mortality in hospitalized COVID-19 patients in June, ${ }^{44}$ was not the most widely used. 
The health system in Peru is fragmented and is currently overwhelmed. ${ }^{45}$ Although progress has been made in universal insurance for the population, ${ }^{46}$ the designated health budget is $2.3 \%$ of the annual gross domestic product. ${ }^{47}$ Moreover, despite the low budget assigned, it is not fully executed annually, ${ }^{47}$ which could further explain the shortcomings of the health system. In Peru, there were approximately 0.2 ICU beds per 100,000 inhabitants before the pandemic, ${ }^{27}$ which, in addition to the deficit of oxygen and hospital beds, could explain the high mortality that led Peru to occupy the first place in mortality per 100,000 inhabitants for several months. ${ }^{48}$ Likewise, the infodemic and high prevalence of selfmedication are two latent problems in the Peruvian population. ${ }^{1,49}$ Both of these behaviors could increase the mortality of COVID-19 by providing false security and by people not attending health services in a timely manner, leading to a worse prognosis. The same occurs with the use of corticosteroids in the early and mild stages of the disease. ${ }^{50}$ On the other hand, the high rate of job informality and poverty in Peru has also aggravated the situation and could explain the poor adherence to quarantine and the failure to implement community mitigation strategies. ${ }^{51}$ This was reflected in a high mortality rate, especially in vulnerable groups. ${ }^{52}$

This study has limitations: 1) The population included in the study were patients insured by social security, which is made up of salaried workers and their families, which may not be representative of the entire country due to its socioeconomic characteristics; 2) There was a high percentage of missing values in certain relevant laboratory markers, which limited their evaluation in the multivariate model. However, relevant and useful markers described in the literature were included; 3) There are laboratory markers of immune response such as cytokines that could not be measured in the present analysis. Despite these limitations, this study represents one of the first reports from Peru, ${ }^{12,53}$ a country that became the global epicenter of the pandemic and leaves many lessons to be dealt with in the future to improve the failures of the health system and management of evidence-based disease.

\section{Conclusions}

The risk factors found are consistent with what has been described in the literature and allow the identification of vulnerable groups in whom monitoring and early identification of symptoms should be prioritized. Likewise, the findings of our study describe what happened during the first stage of the pandemic in Peru, highlighting the late arrival to receiving medical attention, as well as the lack of ICU beds, leading to a high incidence of mortality. In addition, the number of ICU beds, hospital beds and access to oxygen in the population should be improved in order to reduce mortality. Finally, evidence-based treatment schemes must be implemented to combat the infodemic and self-medication in the population of Peru.

\section{Acknowledgments}

We would like to thank the staff of the Hospital Almanzor Aguinaga Asenjo, Luis Heysen Incháustegui and the EsSalud Chepén Hospital Clinic for the logistical support provided. In addition, we would like to thank the Universidad Científica del Sur, for the financial support in the payment of the article processing charge.

\section{Data availability}

Underlying data

Figshare: Database including information of COVID-19 patients from Peru. DOI: https://doi.org/10.6084/m9.figshare.14170955.v1.54

This project contains the following underlying data:

- .xls file containing the information of COVID-19 patients from Peru.

Data are available under the terms of the Creative Commons Zero "No rights reserved" data waiver (CC BY 4.0 Public domain dedication).

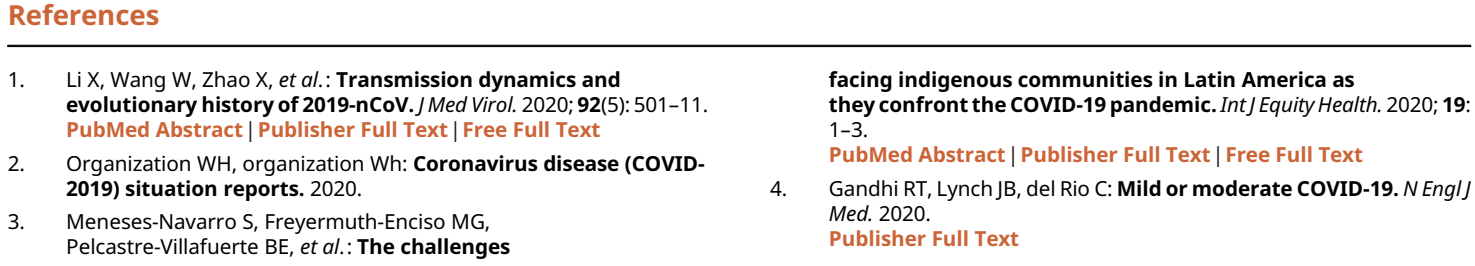

1. Li X, Wang W, Zhao X, et al.: Transmission dynamics and evolutionary history of 2019-nCoV.J Med Virol. 2020; 92(5): 501-11. PubMed Abstract | Publisher Full Text | Free Full Text

2. Organization $\mathrm{WH}$, organization Wh: Coronavirus disease (COVID2019) situation reports. 2020.

3. Meneses-Navarro S, Freyermuth-Enciso MG, Pelcastre-Villafuerte BE, et al.: The challenges

facing indigenous communities in Latin America as they confront the COVID-19 pandemic. Int J Equity Health. 2020; 19: $1-3$.

PubMed Abstract | Publisher Full Text | Free Full Text

4. Gandhi RT, Lynch JB, del Rio C: Mild or moderate COVID-19. N EnglJ Med. 2020.

Publisher Full Text 
5. Yang AP, Liu J, Tao W, et al. The diagnostic and predictive role of NLR, d-NLR and PLR in COVID-19 patients. Int Immunopharmacol. 2020: 106504

PubMed Abstract | Publisher Full Text | Free Full Text

6. Zhou F, Yu T, Du R, et al.: Clinical course and risk factors for mortality of adult inpatients with COVID-19 in Wuhan, China: a retrospective cohort study. Lancet. 2020. PubMed Abstract | Publisher Full Text | Free Full Text

7. Zheng Z, Peng $F, X u$ B, et al.: Risk factors of critical \& mortal COVID-19 cases: A systematic literature review and metaanalysis. J Infect. 2020.

PubMed Abstract | Publisher Full Text | Free Full Text

8. Munayco C, Chowell G, Tariq A, et al.: Risk of death by age and gender from CoVID-19 in Peru, March-May, 2020. Aging (Albany NY). 2020; 12(14): 13869

9. Fraser B: COVID-19 strains remote regions of Peru. Lancet. 2020; 395(10238): 1684.

PubMed Abstract | Publisher Full Text | Free Full Text

10. Dyer O: Covid-19 hot spots appear across Latin America. $B M J$. 2020.

PubMed Abstract | Publisher Full Text

11. Alvarez-Risco A, Mejia CR, Delgado-Zegarra J, et al.: The Peru Approach against the COVID-19 Infodemic: Insights and Strategies. Am J Trop Med Hyg. 2020: tpmd200536. PubMed Abstract | Publisher Full Text | Free Full Text

12. Mejía F, Medina C, Cornejo E, et al.: Oxygen saturation as a predictor of mortality in hospitalized adult patients with COVID-19 in a public hospital in Lima, Peru. PloS One. 2020; 15(12): e0244171.

PubMed Abstract | Publisher Full Text | Free Full Text

13. Mikami T, Miyashita H, Yamada T, et al.: Risk factors for mortality in patients with COVID-19 in New York City. J Gen Intern Med. 2020: $1-10$.

PubMed Abstract | Publisher Full Text | Free Full Text

14. Giesen C, Diez-Izquierdo L, Saa-Requejo CM, et al.: Epidemiological characteristics of the COVID-19 outbreak in a secondary hospital in Spain. Am J Infect Control. 2020. PubMed Abstract | Publisher Full Text | Free Full Text

15. Soares RCM, Mattos LR, Raposo LM: Risk factors for hospitalization and mortality due to COVID-19 in Espírito Santo State, Brazil. Am J Trop Med Hyg. 2020; 103(3): 1184-90. PubMed Abstract | Publisher Full Text | Free Full Text

16. Cortés-Tellés A, López-Romero S, Mancilla-Ceballos R, et al.: Risk factors for mortality among hospitalized patients with COVID19.Tuberculosis and Respiratory Diseases. An overview in Mexican population. 2020.

17. Hypoxia in COVID-19: Sign of Severity or Cause for Poor Outcomes. In: Kashani KB, editor Hypoxia in COVID-19: Sign of Severity or Cause for Poor Outcomes. Mayo Clin Proc 2020; Mayo Foundation for Medical Education and Research.

PubMed Abstract | Publisher Full Text | Free Full Text

18. Teo J: Early detection of silent hypoxia in Covid-19 pneumonia using smartphone pulse oximetry. J Med Syst. 2020; 44(8): 1-2. PubMed Abstract | Publisher Full Text | Free Full Text

19. Shahid Z, Kalayanamitra R, McClafferty B, et al.: COVID-19 and older adults: what we know. J Am Geriatr Soc. 2020; 68(5): 926-9. PubMed Abstract | Publisher Full Text | Free Full Text

20. Pence BD: Severe COVID-19 and aging: are monocytes the key? GeroScience. 2020; 42(4): 1051-61. PubMed Abstract | Publisher Full Text | Free Full Text

21. Rodriguez-Morales AJ, Cardona-Ospina JA, Gutiérrez-Ocampo E, et al.: Clinical, laboratory and imaging features of COVID-19: A systematic review and meta-analysis. Travel Med Infect Dis. 2020; 101623.

PubMed Abstract | Publisher Full Text | Free Full Text

22. Wang $D, H u B, H u$ C, et al.: Clinical characteristics of 138 hospitalized patients with 2019 novel coronavirus-infected pneumonia in Wuhan, China. JAMA. 2020; 323(11): 1061-9. PubMed Abstract | Publisher Full Text | Free Full Text

23. Liu Y, Du X, Chen J, et al.: Neutrophil-to-lymphocyte ratio as an independent risk factor for mortality in hospitalized patients with COVID-19. J Infect. 2020.

PubMed Abstract | Publisher Full Text | Free Full Text

24. Kerboua KE: NLR: A Cost-effective Nomogram to Guide Therapeutic Interventions in COVID-19. Immunol Invest. 2020 1-9. PubMed Abstract | Publisher Full Text

25. Association between hypoxemia and mortality in patients with COVID-19. In: Xie J, Covassin N, Fan Z, et al., editors. Association between hypoxemia and mortality in patients with COVID-19. Mayo Clin Proc 2020: Elsevier.

PubMed Abstract | Publisher Full Text | Free Full Text
26. Petrilli CM, Jones SA, Yang J, et al.: Factors associated with hospital admission and critical illness among 5279 people with coronavirus disease 2019 in New York City: prospective cohort study. BMJ. 2020; 369 .

PubMed Abstract | Publisher Full Text | Free Full Text

27. Almeida F: Exploring the impact of COVID-19 on the sustainability of health critical care systems in South America. Int J Health Policy Manag. 2020.

PubMed Abstract | Publisher Full Text

28. Cavezzi A, Troiani E, Corrao S: COVID-19: hemoglobin, iron, and hypoxia beyond inflammation. A narrative review. Clin Pract. 2020; 10(2)

PubMed Abstract | Publisher Full Text | Free Full Text

29. Pranata R, Lim MA, Huang I, et al.: Hypertension is associated with increased mortality and severity of disease in COVID-19 pneumonia: a systematic review, meta-analysis and metaregression. J Renin Angiotensin Aldosterone Syst. 2020; 21(2). PubMed Abstract | Publisher Full Text | Free Full Text

30. Yang J, Tian C, Chen Y, et al.: Obesity aggravates CoviD-19: an updated systematic review and meta-analysis. J Med Virol. 2020 PubMed Abstract | Publisher Full Text | Free Full Text

31. Huang I, Lim MA, Pranata R: Diabetes mellitus is associated with increased mortality and severity of disease in COVID-19 pneumonia-a systematic review, meta-analysis, and metaregression. Diabetes Metab Syndr. 2020. PubMed Abstract | Publisher Full Text | Free Full Text

32. Collaborators GO: Health effects of overweight and obesity in 195 countries over 25 years. N Engl J Med. 2017; 377(1): 13-27. PubMed Abstract | Publisher Full Text | Free Full Text

33. Kass DA, Duggal P, Cingolani O: Obesity could shift severe COVID19 disease to younger ages. Lancet (London, England). 2020. PubMed Abstract | Publisher Full Text | Free Full Text

34. Lansbury L, Lim B, Baskaran V, et al.: Co-infections in people with COVID-19: a systematic review and meta-analysis. J Infect. 2020.

PubMed Abstract | Publisher Full Text | Free Full Text

35. Gautret $P$, Lagier J-C, Parola P, et al.: Hydroxychloroquine and azithromycin as a treatment of COVID-19: results of an openlabel non-randomized clinical trial. Int J Antimicrob Agents. 2020; 105949.

PubMed Abstract | Publisher Full Text | Free Full Text

36. Ministerio de Salud del Perú: N 193-2020-MINSA. Documento Técnico: Prevención, Diagnóstico y Tratamiento de personas afectadas por COVID-19 en el Perú. 2020.

37. Consortium WST: Repurposed antiviral drugs for COVID-19interim WHO SOLIDARITY trial results. N EnglJ Med. 2020. PubMed Abstract | Publisher Full Text | Free Full Text

38. Hernandez AV, Roman YM, Pasupuleti V, et al.: Hydroxychloroquine or chloroquine for treatment or prophylaxis of COVID-19: a living systematic review. Ann Intern Med. 2020.

PubMed Abstract | Publisher Full Text

39. Soto-Becerra P, Culquichicón C, Hurtado-Roca Y, et al.: Real-world effectiveness of hydroxychloroquine, azithromycin, and ivermectin among hospitalized COVID-19 patients: results of a target trial emulation using observational data from a nationwide healthcare system in Peru. Azithromycin, and Ivermectin Among Hospitalized COVID-19 Patients: Results of a Target Trial Emulation Using Observational Data from a Nationwide Healthcare System in Peru. 2020.

40. Caly L, Druce JD, Catton MG, et al.: The FDA-approved drug ivermectin inhibits the replication of SARS-CoV-2 in vitro. Antiviral Res. 2020; 104787

PubMed Abstract | Publisher Full Text | Free Full Text

41. Zavala-Flores E, Salcedo-Matienzo J: Medicación prehospitalaria en pacientes hospitalizados por COVID-19 en un hospital público de Lima-Perú. Acta Médica Peruana. 2020; 37(3): 393-5. Publisher Full Text

42. Ramal-Asayag C, Espinoza-Venegas LA, Celis-SalinasJC, et al.: Úlcera dérmica por ivermectina subcutánea en el tratamiento de COVID-19. Rev Soc Peru Med Interna. 2020: 88-.

Publisher Full Text

43. Podder CS, Chowdhury N, Sina MI, et al.: Outcome of ivermectin treated mild to moderate COVID-19 cases: a single-centre, open-label, randomised controlled study. IMCJ Med Sci. 2020; 14 (002). Publisher Full Text

44. Group RC: Dexamethasone in hospitalized patients with Covid19-preliminary report. N EnglJ Med. 2020. PubMed Abstract | Publisher Full Text | Free Full Text

45. Atun R, De Andrade LOM, Almeida G, et al.: Health-system reform and universal health coverage in Latin America. Lancet. 2015; 385 
(9974): 1230-47.

PubMed Abstract | Publisher Full Text

46. Mezones-Holguín E, Amaya E, Bellido-Boza L, et al.: Cobertura de aseguramiento en salud: el caso peruano desde la Ley de Aseguramiento Universal. Rev Peru Med Exp Salud Publica. 2019; 36: 196-206.

PubMed Abstract | Publisher Full Text

47. García E: Comex: Perú gasta en salud por debajo del promedio en América Latina. Diario Gestión. 2019. Reference Source

48. Solari LM: Peru-The Role of the National Government in Combatting the COVID-19 Pandemic. Good Public Governance in a Global Pandemic. 465.

49. Urrunaga-Pastor D, Benites-Zapata VA, Mezones-Holguín E: Factors associated with self-medication in users of drugstores and pharmacies in Peru: an analysis of the National Survey on User Satisfaction of Health Services, ENSUSALUD 2015. F1000Res. 2019; 8.

PubMed Abstract | Publisher Full Text | Free Full Text
50. Pasin L, Navalesi P, Zangrillo A, et al.: Corticosteroids for Patients With Coronavirus Disease 2019 (COVID-19) With Different Disease Severity: A Meta-Analysis of Randomized Clinical Trials. J Cardiothorac Vasc Anesth. 2020

PubMed Abstract | Publisher Full Text | Free Full Text

51. Analytica O: COVID-19 will have wide-ranging impacts in Peru. Emerald Expert Briefings. (oxan-db).

52. Aguirre-Amaya K, Palomares-Custodio M, Quispe-Vicuña C, et al.: COVID-19 Mortality in Peruvian Older Adults: A Chronicle of a Health Crisis Foretold? J Frailty Aging. 2020: 1-2. PubMed Abstract | Publisher Full Text | Free Full Text

53. Benites-Goñi $H$, Vargas-Carrillo $E$, Peña-Monge $E$, et al.: Clinical characteristics, management and mortality of patients hospitalized with COVID-19 in a reference hospital in Lima, Peru. Clinical characteristics, management and mortality of patients hospitalized with COVID-19 in a reference hospital in Lima, Peru. 2020.

54. Urrunaga-Pastor D: Database_v1. figshare. Dataset. 2021. Publisher Full Text 


\section{Open Peer Review}

\section{Current Peer Review Status:}

\section{Version 1}

Reviewer Report 15 June 2021

https://doi.org/10.5256/f1000research.54648.r83302

(C) 2021 Cadena Sanabria M. This is an open access peer review report distributed under the terms of the Creative Commons Attribution License, which permits unrestricted use, distribution, and reproduction in any medium, provided the original work is properly cited.

\section{Miguel Oswaldo Cadena Sanabria}

Internal Medicine Department, University Hospital of Santander, Industrial University of Santander, Bucaramanga, Colombia

The present study includes clinical and sociodemographic data in a cohort of Peruvian adults with COVID-19 and describes the factors associated with mortality. The authors demonstrated the concordance of the variables and medical conditions associated with higher mortality. It is a population with high mortality, less than $80 \%$ of the patients received steroids according to the recovery study protocol; however, given that the population was evaluated between March to May 2020, there was still uncertainty in effective treatments. Remarkably, the male gender was not associated with a higher risk of dying from COVID-19. There is adequate methodology and coherence with the results and conclusions.

It should be noted that only $3.4 \%$ of the cases were confirmed with a positive RT-PCR test. Serological diagnoses (IgM/IgG) tend to be later and may be related to an increased risk of mortality. Today, antigenic tests are available, which also allow a faster diagnosis.

The Cox regression model is adequate for the purpose of the study. The authors adequately recognize biases and limitations, as well as the number of losses in paraclinical variables.

This study is based on a hospital population with a census sample (it included all the cases that met the inclusion criteria). This limits the external validity or generalizability of the results. Mortality is oversized since it does not represent the risk of lethality in the general population with COVID-19. Another aspect associated with higher mortality could have been the limitation in admission to the intensive care unit, only $3.3 \%$ of the patients were admitted. These key aspects are recognized by the researchers and are part of the paper.

Is the work clearly and accurately presented and does it cite the current literature? Yes

Is the study design appropriate and is the work technically sound? 
Yes

Are sufficient details of methods and analysis provided to allow replication by others? Yes

If applicable, is the statistical analysis and its interpretation appropriate?

Yes

Are all the source data underlying the results available to ensure full reproducibility?

Yes

Are the conclusions drawn adequately supported by the results?

Yes

Competing Interests: No competing interests were disclosed.

Reviewer Expertise: Internal Medicine, Geriatrics, Medical Education

I confirm that I have read this submission and believe that I have an appropriate level of expertise to confirm that it is of an acceptable scientific standard.

Reviewer Report 25 May 2021

https://doi.org/10.5256/f1000research.54648.r84549

(c) 2021 Gómez Montes J. This is an open access peer review report distributed under the terms of the Creative Commons Attribution License, which permits unrestricted use, distribution, and reproduction in any medium, provided the original work is properly cited.

\section{José Fernando Gómez Montes}

Research Group in Geriatrics and Gerontology, Faculty of Health Sciences, Universidad de Caldas, Manizales, Colombia

\section{General comment}

This is a retrospective cohort study about of the risk factors for mortality in patients hospitalized for COVID-19 in three hospitals in Peru in 2020. The topic of the manuscript is appropriate for the Journal. It is of high interest to investigators and clinicians. Their findings provide valuable information about risk factors associated with deaths in developing countries; these results can be considerably useful for epidemiological description of the disease in terms of person-level risk. Minor essential revisions are necessary.

\section{Minor essential revisions}

Tittle:

The title is accurate and sufficiently descriptive of the content.

The title is consistent with the presented problem and reflects the main message of the 


\section{Abstract:}

study.

Abstract: Concise and specific.

Main objective of the review is presented.

Abstract highlights the contribution of this work.

\section{Introduction:}

The background of the study is clear and helpful to readers unfamiliar with the subject.

The purpose of the article is clearly presented.

Information is clearly provided.

\section{Methods:}

The approach and study design are appropriateness.

More information about serological and molecular test for Covid-19 is desirable.

What are the requirements to be hospitalized in ICU? Please provide what ICU admission criteria were used.

\section{Discussion:}

The discussion is relevant.

Conclusions are logically valid and justified by evidence about the main theme proposed.

\section{References:}

There were 54 and all are appropriate and relevant. However check references carefully; for example references 16.27.36.47.48.50. 51.53.54 are no complete; please provide them according to journal requirements.

\section{Tables and figures:}

Three tables and three figures are shown. All of them clear and well designed.

Thanks for letting me review this manuscript. This could be a nice paper.

Level of interest: An article whose findings are important to those with closely related research interests.

Quality of written English: Well.

Statistical review: No.

Declaration of competing interests: I declare that I have no competing interest.

Is the work clearly and accurately presented and does it cite the current literature? Yes

Is the study design appropriate and is the work technically sound?

Yes

Are sufficient details of methods and analysis provided to allow replication by others? Yes

If applicable, is the statistical analysis and its interpretation appropriate? 
Yes

Are all the source data underlying the results available to ensure full reproducibility? Yes

Are the conclusions drawn adequately supported by the results?

Yes

Competing Interests: No competing interests were disclosed.

Reviewer Expertise: Geriatrics, Falls, Frailty Geriatric syndromes

I confirm that I have read this submission and believe that I have an appropriate level of expertise to confirm that it is of an acceptable scientific standard.

\section{Comments on this article}

\section{Version 1}

Reader Comment 19 Mar 2021

Alfonso Rodriguez-Morales, Fundacion Universitaria Autonoma de las Americas, Pereira, Colombia

This is a very interesting and timely article. Even after one year of the COVID-19 pandemic, there is still a lack of studies assessing the risk factors for mortality in hospitalized patients, especially in Peru. For example, in Bolivia, we performed early in the pandemic, March 2020, a similar study:

Escalera-Antezana JP, Lizon-Ferrufino NF, Maldonado-Alanoca A, Alarcon-De-la-Vega G, AlvaradoArnez LE, Balderrama-Saavedra MA, Bonilla-Aldana DK, Rodriguez-Morales AJ. Risk factors for mortality in patients with Coronavirus Disease 2019 (COVID-19) in Bolivia: An analysis of the first 107 confirmed cases. Infez Med. 2020 Jun 1;28(2):238-242.

We found that at the multivariate analysis (logistic regression), two variables remained significantly associated, age, being 60 years old or more (OR=9.4, 95\%CI 1.8-104.1), and hypertension (OR=3.3, 95\%CI 1.3-6.3). As expected, age and comorbidities, particularly hypertension, were independent risk factors for mortality in Bolivia in the first 107 cases group.

In this study from Peru, consistently, being 60 years old or older also increased the risk of mortality, as well as having two or more comorbidities (HR=1.53; 95\% CI: 1.10-2.14), such as hypertension.

Still, COVID-19 represents a threat to global health, and risk groups should be carefully assessed by clinicians in order to treat early them. Congratulations on this study! 
Competing Interests: None.

The benefits of publishing with F1000Research:

- Your article is published within days, with no editorial bias

- You can publish traditional articles, null/negative results, case reports, data notes and more

- The peer review process is transparent and collaborative

- Your article is indexed in PubMed after passing peer review

- Dedicated customer support at every stage

For pre-submission enquiries, contact research@f1000.com 